УДК 616.12-007.2-053.2-07:618.33

\title{
Experience of ultrasound diagnostics of vascular rings and its influence on surgical treatment
}

\author{
Pavlova A. ${ }^{1}$, Kurkevych A. ${ }^{1}$, Rudenko N. ${ }^{1,2}$, Ialynska T. ${ }^{1}$, Yemec R.1, Yemec I. ${ }^{1}$ \\ ${ }^{1}$ Ukrainian Children's Cardiac Centre (Kiev) \\ ${ }^{2}$ Shupyk National Medical Academy of Postgraduate Education (Kiev)
}

\begin{abstract}
Contemporary methods diagnose congenital heart diseases (CHD) with high accuracy but postnatal diagnostics of vascular rings (VR) remains difficult. From 2004 to 2017 in our Center were performed 7740 primary fetal echocardiograms and more than 65,000 echocardiograms for children. From 2004 to 201718589 operations of congenital heart disease were performed, of them $95(0,51 \%)$ were VR surgery. Of all patients treated with VR $21(22,1 \%)$ had prenatal diagnosis, $74(77,9 \%)$ - had postnatal. Since 2011 during postnatal and prenatal echocardiography, we introduced a new protocol with necessary views for VR visualization. Thanks to the use it increased the number of operations on the VR. Surgical treatment of VR has excellent results with low surgical risk. For the successful VR surgical treatment is necessary CT to perform for required to clarify the anatomy of the VR and the trachea. Prenatal and postnatal Echo can help of VR detection in a group of asymptomatic patients.
\end{abstract}

Key words: vascular ring, prenatal diagnosis, echocardiography, surgical treatment.

The term vascular ring (VR) is now used for all congenital anomalies of vessels of the aorta system, which cause compression of the trachea and esophagus. This is an extremely rare pathology and accounts for less than $1 \%$ of all CHD. Congenital anomalies of the aortic arch have been known at least since 1735, when Hunauld described an abnormal right subclavian artery, Hommel in 1737 - the double arch of the aorta, Fioratti and Aglietti - the right arch of the aorta in 1763. Correlation of clinical manifestations of swallowing disorders with the presence of an abnormal right subclavian artery was presented to Bayford at a meeting of the Medical Association in London in 1787 and published in 1794. However, there was no significant clinical interest in this group of anomalies until the 1930s, when the use of barium esophagography was introduced. Then there was an opportunity to diagnose some anomalies of the aortic arch during the lifetime, and not only as a result of pathologic-anatomical sections. Then surgical methods of treatment of various anatomical variants of pathology of the aortic arc began to develop. For the first time the term "vascular ring" was used in literature in 1945 by Dr. Robert Gross from Boston Children's Hospital. He described two classical variants of complete vascular rings - the double artery of the aorta and the right arch of the aorta with the left arterial ligament. Modern interest in these abnormalities was caused by the first surgical correction of the double aortic arch in 1945. Subsequently, he first performed surgical treatment and most other forms of VR. In modern cardiac surgery, the results of VR treatment are excellent and most patients have complete disappearance of symptoms [1,2].
Despite the fact that modern methods of diagnosing congenital heart defects are accurate, postnatal diagnostics of the VR remains difficult. At present, the best method for diagnosis of VR is CT, which can accurately determine the anatomy of the VR and the associated trachea pathology [3-5].

Echocardiography does not provide such amount of information for the diagnosis of VR as CT. However, this is a safe method, which, while using the necessary projection, still allows you to diagnose VR. Particularly important is the echocardiographic fetus, which allows you to diagnose the VR before the baby is born [6-8].

Objective. The purpose of the study was to analyze the effectiveness of ultrasound diagnosis of VR and its effect on surgical treatment.

Materials and methods. From 2004 to 2017, 18589 surgical operations for CHD were performed at our Center (Fig.1). From 2004 to 2017, more than 65,000 echocardiographs of children under the age of 18 were and 7740 primary examinations of pregnant women conducted at our Center. All tests were performed by the method of transthoracic echocardiography and transabdominal fetal echocardiography on ultrasound scanners Philips Sonos 7500, Siemens Acuson Sequoia 512, Philips iU22, Philips iE33, Philips EPIQ 7 with the convection transducer with 9-1 MHz and sector transducers with $12 \mathrm{MHz}, 8 \mathrm{MHz}, 4-1$ $\mathrm{MHz}$ operating frequency. Computer tomography (CT) to confirm the ultrasound diagnosis of VR was performed on a 16-slice tomography Siemens Somatom Sensation

Results and discussion. From 2007 to 2017 in our Center $95(0,51 \%)$ surgical interventions were performed with the 


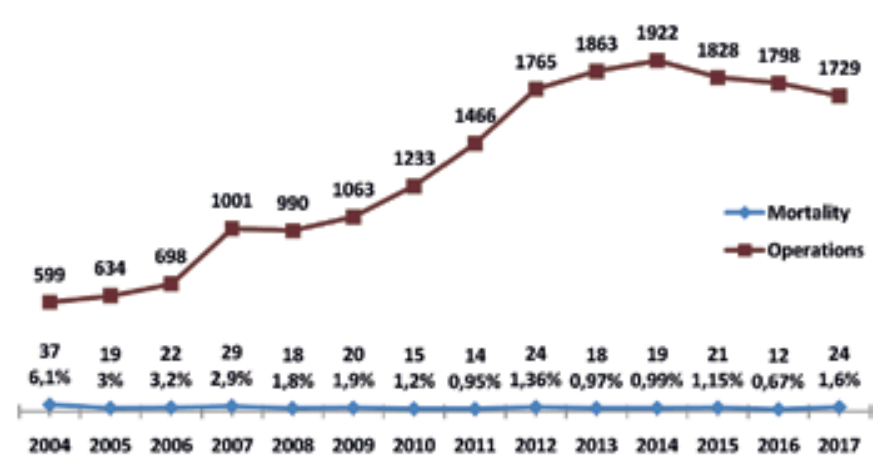

Fig. 1. Dynamics of all surgical operations and lethality for 13 years (2004-2017)

Table 1

The number of prenatally diagnosed $V R$

\begin{tabular}{cc} 
Year & The number of prenatally diagnosed VR \\
\hline 2012 & 3 \\
\hline 2013 & 2 \\
\hline 2014 & 11 \\
\hline 2015 & 12 \\
\hline 2016 & 14 \\
\hline 2017 & 28
\end{tabular}

removal of the VR. In this group of patients there was no early and late postoperative lethality. In $54(56,8 \%)$ cases, the VR was isolated, in $41(43,2 \%)$ - in combination with another CHD. Of the patients treated for VR $21(22,1 \%)$ had prenatal diagnosis, $74(77,9 \%)$ had postnatal diagnosis. Until 2010 postnatal diagnosis of VR was established against the backdrop of clinical symptoms trachea and esophageal compression, or, as a casual finding, during a CT scan with regard to the associated CHD. Since 2011 during the postnatal echocardiography, a new protocol was introduced with the necessary projections for VR diagnosis:

1) evaluation of the anatomy of the aortic arch (the origin of

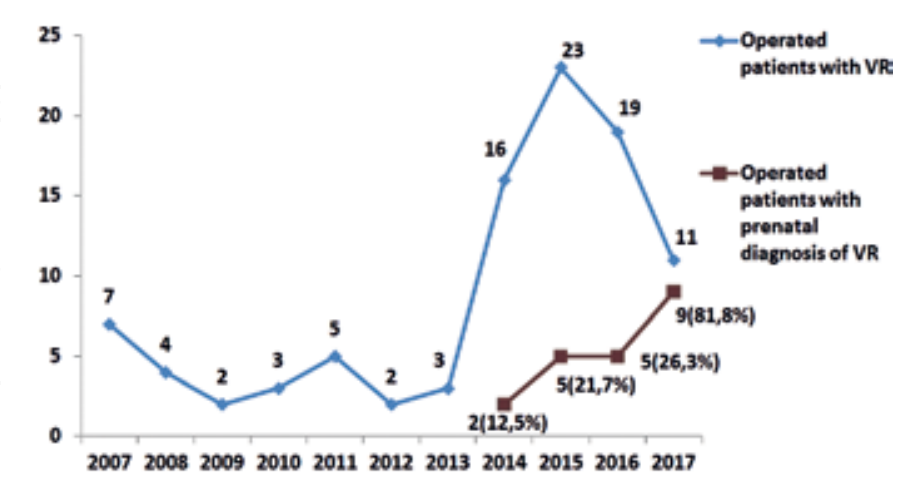

Fig. 3. Dynamics of surgical treatment of patients with prenatal diagnosis of $V R$

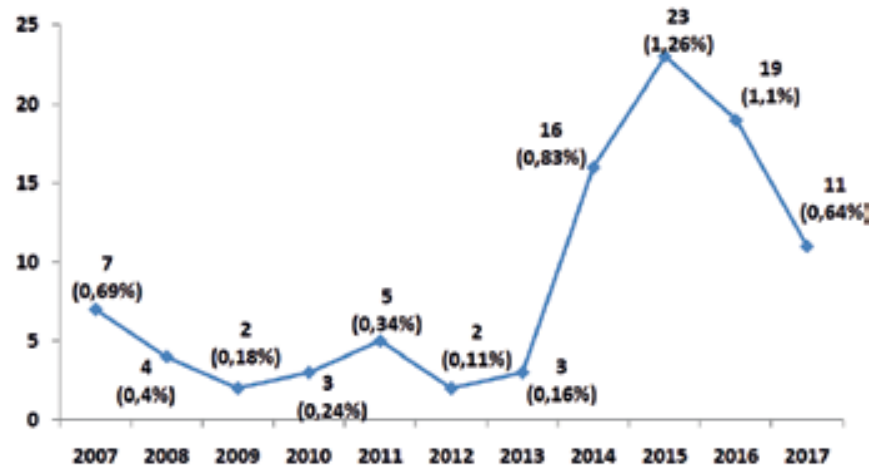

Fig. 2. An increase in the surgical treatment of patients with VR in 13 years (2004-2017)

the brachiocephalic trunk and the presence of its branching); 2) the aortic arch long-axis view (the arch of normal for patient-sized in the typical projection with the origin of 3 vessels); 3) the transverse view of the upper abdomen (for the evaluation the position of abdomen part of aorta). Thanks to the introduction of the new postnatal echocardiographic protocol, it has been possible to significantly improve the postnatal diagnosis of VR. Since 2013 due to this increased the number of VR operations (Fig. 2).

Since 2011 during the conduction of the fetal echocardiography a new protocol with the necessary views for diagnostics of the VR was made: 1) the 3-vessel and trachea view, 2) the aortic arch long-axis view, 3) the transverse view of the upper abdomen. Thanks to the introduction of the new protocol, the echocardiography of the fetus has been able to significantly improve the prenatal diagnosis of VR. From 2012 to 2017 the growth of the number of prenatally diagnosed VR (Table 1) is recorded [9].

From 2014 to 201721 patients with prenatal diagnosis of VR were operated (Fig. 3). In the articles of many authors, the wide introduction of additional methods of VR diagnosis - such as ultrasound diagnostics, MRI and bronchoscopy is used to reduce $\mathrm{X}$-rays. This is especially true for young children $[3,5,6]$. However, in order to determine the optimal path of surgical treatment, it is necessary to know the anatomy of the VR and the trachea perfectly. At the present stage, only CT allows the image of the artery of the aorta and its vessels and trachea of the required quality $[1,4]$. Nevertheless, ultrasound diagnosis of VR is a non-invasive, safe diagnostic method that does not require special patient preparation and can be widely used as a screening method for prenatal and postnatal diagnosis of VR.

Conclusions. Surgical treatment of VR has excellent results with low surgical risk. Despite the fact that for the successful surgical treatment of VR is necessary CT to perform for required to clarify the anatomy of the VR and the trachea, prenatal and postnatal ultrasound diagnostics of the VR allows the detection of a group of asymptomatic patients. 


\section{References}

1. Vascular rings / Backer C. L., Mongŭ M. C., Popescu A. R. et al. // Semin Pediatr Surg. - 2016 Jun. - Vol. 25 (3). P. $165-75$.

2. Vascular Ring Diagnosis and Management: Notable Trends Over 25 Years / Evans W. N., Acherman R. J., Ciccolo M. L. et al. // World J Pediatr Congenit Heart Surg. - 2016 Nov. - Vol. 7 (6). - P. 717-20.

3. Imaging modalities in children with vascular ring and pulmonary artery sling / Leonardi B., Secinaro A., Cutrera R. et al. // Pediatr Pulmonol. - 2015 Aug. Vol. 50 (8). - P. 781-8.

4. Simulation analysis of airflow alteration in the trachea following the vascular ring surgery based on CT images using the computational fluid dynamics method / Chen F. L., Horng T. L., Shih T. C. // J Xray Sci Technol. 2014. - Vol. 22 (2). - P. 213-25.
5. Congenital vascular rings: a clinical challenge for the pediatrician / Licari A., Manca E., Rispoli G. A. et al. // Pediatr. Pulmonol. - 2015. - Vol. 50. - P. 511.

6. Prenatal Sonographic Features of a Double Aortic Arch: Literature Review and Perinatal Management / Trobo D., Bravo C., Alvarez T. et al. // J Ultrasound Med. - 2015 Nov. - Vol. 34 (11). - P. 1921-7.

7. Fetuses with right aortic arch: a multicenter cohort study and meta-analysis / D'Antonio F., Khalil A., Zidere V. et al. // Ultrasound Obstet Gynecol. -2016 Apr. - Vol. 47 (4). - P. 423-32.

8. Prenatal diagnosis and outcome of right aortic arch without significant intracardiac anomaly / Razon Y., Berant M., Fogelman R., Amir G., Birk E. // J Am Soc Echocardiogr. 2014 Dec. - Vol. 27 (12). - P. 1352-8.

9. Vplyv prenatalnoho diahnozu sudynnoho kiltsia na perynatalne vedennia ta likuvalnu taktyku / Pavlova A. O. // Visnyk Sertsevo Sudynnoi Khirurhii. - 2018. - Vol. 2 (31).- P. 77-80.

\title{
Досвід ультразвукової діагностики судинних кілець та його вплив на хірургічне лікування
}

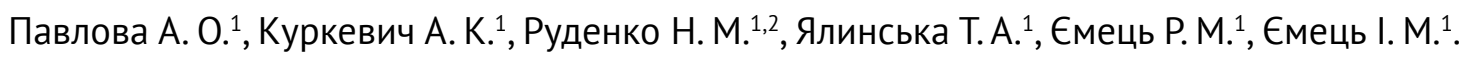 \\ ${ }^{1}$ ДУ «Науково-практичний медичний центр дитячої кардіології та кардіохірургії МОЗ України» (Київ) \\ ${ }^{2}$ Національна медична академія післядипломної освіти імені П. Л. Шупика
}

Термін судинне кільце (СК) сьогодні застосовується для всіх вроджених аномалій судин системи аорти (АО), які спричиняють стиснення трахеї та стравоходу. Це вкрай рідкісна патологія, яка становить менше $1 \%$ усіх вроджених вад серця (BВC). Незважаючи на те, що сучасні методи дозволяють діагностувати вроджені вади серця з високою точністю, проте постнатальна діагностика судинного кільця залишається складною. На сьогоднішній день найкращим методом діагностики СК є комп'ютерна томографія (КТ), завдяки якій можна з високою точністю визначити анатомію СК та пов’язану з ним патологію трахеї [3-5]. Ехокардіографія (ЕхоКГ) не дає такого обсягу інформації, проте це безпечний метод, який при використанні певних проекцій дозволяє діагностувати наявність СК. Особливо важливою є ЕхоКГ плода, яка дозволяє встановити діагноз СК ще до народження дитини [6-8].

Мета роботи - аналіз ефективності ранньої ультразвукової діагностики (УЗД) СК та ії вплив на хірургічне лікування.

Матеріали та методи. 32004 по 2017 pр. у нашому Центрі всього було проведено більше 65000 обстежень дітей до 18 років методом ЕхоКГ та 7740 первинних ЕхоКГ плода. Було здійснено 18589 оперативних втручань з приводу ВВС. Всі обстеження проводились методом трансторакальної та трансабдомінальної ЕхоКГ на ультразвукових сканерах Philips Sonos 7500, Siemens Acuson Sequoia 512, Philips iU22, Philips iE33 Philips EPIQ 7 за допомогою конвексних датчиків частотою 9-1 МГц та фазованих секторних датчиків частотою 12 МГц, 8 МГц та 4-1 МГц. Для підтвердження ультразвукового діагнозу СК проводилась КТ на 16-зрізовому томографі Siemens Somatom Sensation.

Результати та обговорення. 32007 по 2017 рр. в Центрі було проведено 95 (0,51\%) оперативних втручань з усуненням СК. У цій групі пацієнтів була відсутня рання та пізня післяопераційна летальність. У 54 (56,8\%) випадках CK було ізольованим, у 41 (43,2\%) - поєднаним з іншою ВВС, у 21(22,1\%) випадку діагноз було встановлено пренатально, у 74 (77,9\%) - постнатально. До 2010 р. постнатальний діагноз СК встановлювався на фоні клінічних симптомів стиснення трахеї та стравоходу або, як випадкова знахідка, при проведенні КТ із приводу супутньої ВВС. 3 2011p. при проведенні пренатальної та постнатальної ЕхоКГ було впроваджено новий протокол 3 обов'язковими проекціями для виключення СК, завдяки чому вдалося значно покращити пренатальну та постнатальну діагностику СК, і з 2013р. різко зросла кількість операцій з приводу СК.

Висновки. Хірургічне лікування СК має відмінні результати з низьким хірургічним ризиком. Незважаючи на те, що для успішного хірургічного лікування СК необхідним є проведення КТ для уточнення анатомії СК та трахеї, пренатальна та постнатальна ультразвукова діагностика СК дозволяє виявити групу асимптоматичних пацієнтів.

Ключові слова: судинне кільце, пренатальна діагностика, ехокардіографія, хірургічне лікування. 